\title{
Pengaruh Karakteristik Individual dan Lingkungan Kerja Terhadap Kinerja Pegawai Kantor Dinas Transmigrasi Kabupaten Banyuasin
}

\author{
Oktariansyah \\ Akuntansi, Fakultas Ekonomi Universitas PGRI Palembang \\ rianbro82@univpgri-palembang.ac.id
}

\begin{abstract}
ABSTRAK
Tujuan dari penelitian ini untuk menguji pengaruh karakteristik individual dan lingkungan kerja terhadap kinerja pegawai Kantor Dinas Transmigrasi Kabupaten Banyuasin. Masalah penelitian ini secara parsial dan simultan adakah pengaruh karakteristik individual dan lingkungan kerja terhadap kinerja pegawai. Data dikumpulkan dengan menggunakan angket/kuesioner. Teknik analisis data yang digunakan adalah analisis regresi linier berganda, koefisien determinasi, uji $f$ dan uji t dengan menggunakan program spps for windows versi 22. Hasil uji t diperoleh nilai $\mathrm{t}$ untuk variabel karakteristik individual thitung 2,638 dengan ttabel 2,024 maka dapat disimpulkan bahwa secara persial ada pengaruh antara karakteristik inidividual terhadap kinerja pegawai, sedangkan untuk variabel lingkungan kerja diperoleh thitung sebesar 3,349 dengan tabel 2,024 maka dapat disimpulkan bahwa secara persial ada pengaruh antara lingkungan kerja terhadap kinerja pegawai. Hasil pembahasan diperoleh hasil uji f secara simultan $F_{\text {hitung }}$ sebesar 12,461 dengan $F_{\text {tabel }}$ 3,24 maka dapat disimpulkan bahwa secara simultan terdapat pengaruh yang signifikan antara karakteristik individual dan lingkungan kerja terhadap kinerja pegawai Kantor Dinas Transmigrasi Kabupaten Banyuasin. Koefisien determinasi yang terlihat pada Adjusted $R$ Square sebesar 0,396 atau 39,6\% dan sisanya $60,4 \%$ dipengaruhi oleh faktor-faktor lain yang tidak diteliti.
\end{abstract}

Kata Kunci: Karakteristik Individu, Lingkungan Kerja dan Kinerja.

\section{ABSTRACT}

This study aims to examine the effect of individual characteristics and work environment on the performance of Banyuasin District Transmigration Office employees. The problem of this research is that there is a partial and simultaneous influence of individual characteristics and work environment on employee performance. Data were collected using a questionnaire / questionnaire. The data analysis technique used is multiple linear regression analysis, coefficient of determination, $f$ test and t test using the spps for windows version 22 program. The $t$ test results obtained for the individual characteristics variable $t$ count 2.638 with 2.024 table then it can be concluded that there is a the influence of individual characteristics on employee performance, while for the work environment variables obtained tcount of 3.349 with 2.024 table then it can be concluded that there is a partial influence between the work environment on employee performance. The results of the discussion obtained f test results simultaneously Fcount of 12.461 with Ftable 3.24, it can be concluded that simultaneously there is a significant effect between individual characteristics and work environment on the performance of Banyuasin District Transmigration Office employees. The coefficient of determination seen in Adjusted $R$ Square of 0.396 or $39.6 \%$ and the remaining $60.4 \%$ is influenced by other factors not examined.

Keywords: Individual Characteristics, Work Environment and Performance. 


\section{A. PENDAHULUAN}

Sumber daya yang paling istimewa adalah manusia, yang memiliki kepribadian, perasaan. Setiap individu memiliki ciri kepribadian tersendiri, sehingga terbentuk suatu karakteristik individual. Baik tidaknya kepribadian seseorang tergantung pengaplikasikannya masing-masing.

$$
\text { Sumber daya manusia }
$$

merupakan salah satu faktor terpenting karena tanpa adanya peran dari sumber daya manusia yang berkualitas maka segala aktifitas dalam suatu instansi tidak akan dapat terlaksana secara optimal. Untuk tercapainya kinerja yang baik dan produktifitas yang tinggi, setiap instansi harus menyadari berhasil atau tidaknya tugas dan fungsi yang dilaksanakan tergantung pada faktor sumber daya manusia. Sumber daya manusia yaitu orang-orang yang memberikan tenaga, bakat, kreatifitas dan usahanya kepada organisasi, perusahaan atau instansi. Walaupun canggih sarana dan prasarana yang dimiliki oleh suatu instansi tanpa ditunjang dengan kemampuan pegawai, mustahil instansi tersebut dapat maju dan berkembang.

Karakteristik individual yang berbeda-beda disebabkan oleh usia, jenis kelamin, jumlah tanggungan, status pernikahan dan pengalaman kerja pegawai. Pegawai yang mempunyai karakteristik individu yang baik akan lebih mudah dalam menyelesaikan pekerjaan, sehingga kinerja yang dihasilkan akan optimal dan menjadi sangat baik pengaruhnya untuk perusahaan. Selain karakteristik individual, faktor lain yang mempengaruhi langsung pegawai dan tidak dapat dipisahkan dalam mencapai suatu tujuan pada perusahaan yaitu lingkungan kerja. Lingkugan kerja adalah tempat dimana pegawai melakukan aktivitas kesehariannya, baik fisik maupun non fisik yang ada disekitar para pekerja akan mempengaruhi dirinya dalam menjalankan tugas dan tanggung jawabnya. Pimpinan harus memperhatikan lingkungan kerja pada perusahaan, karena lingkungan yang baik dapat memotivasi pegawai untuk bekerja lebih baik, dan meningkatkan kinerja pegawai dalam perusahaan.

Dari uraian diatas, perusahaan harus mengkondisikan keadaan lingkungan kerja perusahaannya sesuai dengan karakteristik individual pegawainya demi tercapainya tujuan perusahaan secara efektif sehingga dapat meningkatkan kinerja pegawai. Kinerja merupakan pencapaian yang optimal sesuai dengan potensi yang dimiliki oleh seorang pegawai. Kinerja ini menggambarkan sejauh mana seseorang dalam menjalankan tugas dan berusaha untuk mencapai tujuannya.

Karakteristik individual yang berbeda-beda dalam menjalankan aktivitas kerja sehari-hari yang ada di Kantor Dinas Transmigrasi Kabupaten Banyuasin menyebabkan kurangnya inisiatif serta ide-ide yang dikeluarkan oleh pegawai dalam mendukung tujuan organisasi, selain itu kurangnya pengalaman kerja yang dimiliki oleh pegawai sehingga berpengaruh terhadap pencapaian kinerja pegawai. Begitu juga dengan lingkungan kerja yang ada di Kantor Dinas Transmigrasi Kabupaten Banyuasin masih banyak terdapat komponen lingkungan kerja pegawai yang belum mencapai target, seperti ruang kerja yang masih belum efektif, warna dinding kantor yang sudah mulai pudar membuat ruang kerja kurang nyaman, kurangnya kebersihan pada sekitar tempat kerja sehingga menyebarkan bau tidak sedap serta kurangnya perlindungan keamanan lingkungan kantor. 
B. KAJIAN TEORI

\section{1) Pengertian Karakteristik Individual}

Rahman (2013:77) menjelaskan karakteristik individual adalah ciri khas yang menunjukkan perbedaan seseorang tentang motivasi, inisiatif, kemampuan untuk tetap tegar menghadapi tugas sampai tuntas atau memecahkan masalah atau bagaimana menyesuaikan perubahan yang terkait erat dengan lingkungan yang mempengaruhi kinerja individu.

Thoha (2016:33) menjelaskan, bahwa karakteristik individual membawa kedalam tatanan organisasi, kemampuan, kepercayaan pribadi, pengharapan, kebutuhan dan pengalaman masa lalunya. Karakteristik ini yang dimiliki individu ketika akan memasuki suatu lingkungan baru, yakni organisasi. Dari penjelasan diatas, dapat disimpulkan bahwa setiap individu memiliki karakteristik yang berbeda beda, perbedaan ini yang akan mempengaruhi individual karena setiap individual memiliki kepuasan tersendiri walaupun ditempat kerja yang sama.

Hurriyati (2011:79) menjelaskan karakteristik individual adalah suatu proses psikologi yang mempengaruhi individu dalam memperoleh, mengkonsumsi serta menerima barang dan jasa serta pengalaman. Karakteristik merupakan faktor internal yang menggerakan dan mempengaruhi perilaku individual.

Berdasarkan beberapa pendapat diatas, makadapat dikatakan bahwa karakteristik individual meliputi kemampuan, kepercayaan pribadi, pengharapan, kebutuhan dan pengalaman masa lalunya.

\section{2) Pengertian Lingkungan Kerja} Nitisemito dalam Sunyoto (2015:38) mengemukakan bahwa lingkungan kerja adalah segala sesuatu yang ada disekitar para pekerja yang dapat mempengaruhi dirinya dalam menjalankan tugas-tugas yang dibebankan, misalnya kebersihan, musik, penerangan dan lain-lain.

Christensen dalam Uha (2014:57) menjelaskan bahwa lingkungan suatu organisasi bisnis, sosial dan lainnya adalah pola semua kondisi internal, eksternal dan semua pegaruh yang mempengaruhi kehidupan organisasi. Dari pengertian diatas dapat disimpulkan bahwa lingkungan kerja adalah segala sesuatu diluar atau didalam diri individu yang berada dekat dengan individu tersebut sehingga dapat mempengaruhi hasil kerjanya.

\section{Faktor-Faktor Kerja}

Nuraida (2014:174) menjelaskan bahwa faktor-faktor yang termasuk dalam lingkungan kerja yaitu:

a. Cahaya atau penerangan, merupakan faktor penting untuk meningkatkan efisiensi kerja pegawai karena mempengaruhi kesehatan pegawai dan keselamatan kerja serta kelancaran kerja.

b. Warna, merupakan faktor penting untuk meningkatkan efisiensi kerja pegawai.

c. Udara, dalam hal ini lebih dilihat dari sisi suhu atau temperatur, kelembaban, sirkulasi atau ventilasi dan kebersihan.

d. Bunyi atau suara, suara yang gaduh akan menimbulkan gangguan mental dan saraf pegawai, menimbulkan kesulitan berkonsentrasi, mengurangi hasil, meningkatkan kesalahan, menimbulkan kesulitan menerima telepon, menciptakan lebih banyak ketidak hadiran, menambah kelelahan dan mengurangi semangat kerja pegawai. 
e. Musik, dapat mempengaruhi keadaan fisik dan mental pegawai. Musik berguna untuk hal-hal berikut:
1) Meningkatkan $\begin{array}{rr} & \text { efisiensi, } \\ \text { kerja } & \text { dan }\end{array}$ kerja kepuasan produktifitas.

2) Mengurangi ketegangan mental, menimbulkan rasa relax, mengurangi rasa gugup dan kejenuhan serta menambah kegembiraan kerja.

\section{$>\quad$ Indikator Lingkungan Kerja}

Menurut Sedarmayanti (2011:28) indikator-indikatornya sebagai berikut:
a. Penerangan di tempat kerja
b. Temperatur di tempat kerja
c. Sirkulasi udara di tempat kerja
d. Kebisingan di tempat kerja
e. Getaran mekanis di tempat kerja
f. Bau tidak sedap di tempat kerja
g. Tata warna di tempat kerja
h. Dekorasi di tempat kerja
i. Musik di tempat kerja
j. Keamanan di tempat kerja

\section{3) Pengertian Kinerja Pegawai}

Kinerja pegawai merupakan suatu proses tentang bagaimana pekerjaan berlangsung untuk mencapai hasil kerja (Wibowo, 2014:70). Namun, hasil pekerjaan itu sendiri juga menunjukkan kinerja pegawai. Sedangkan Uha (2013:213) menjelaskan kinerja pegawai adalah hasil kerja yang dicapai oleh seseorang atau kelompok orang dalam suatu organisasi sesuai dengan wewenang dan tanggung jawab masing-masing dalam rangka mencapai tujuan masing-masing dalam rangka mencapai tujuan organisasi yang bersangkutan secara legal, tidak melanggar hukum dan sesuai dengan moral dan etika. Berdasarkan penjelasan diatas, dapat disimpulkan bahwa kinerja adalah hasil dari pekerjaan seseorang atau kelompok yang dapat mengambarkan potensi seseorang atau kelompok tersebut selama bekerja.

\section{Indikator Kinerja Pegawai}

Menurut Wibowo (2014:63), indikatornya adalah:

a. Tujuan, merupakan keadaan yang berbeda yang secara aktif dicari oleh seorang individu atau seorang organisasi untuk dicapai.

b. Standar, mempunyai arti penting karena memberitahukan kapan suatu tujuan dapat diselesaikan.

c. Umpan Balik, melaporkan kemajuan, baik kualitas maupun kuantitas dalam mencapai tujuan yang didefinisikan dalam standar.

d. Alat atau Sarana, merupakan sumber daya yang dapat digunakan untuk membantu menyelesaikan tujuan yang sukses.

e. Kompetensi, merupakan persyaratan utama dalam kinerja. Kompetensi merupakan kemampuan yang dimiliki seseorang untuk menjalankan pekerjaan yang diberikan kepadanya dengan baik.

f. Motif, merupakan alat pendorong bagi seseorang untuk melakukan sesuatu.

Peluang, perlu mendapatkan pekerjaan untuk menunjukkan prestasi kerjanya.

\section{METODE PENELITIAN}

Pada penelitian ini penulis menggunakan metode penelitian kuantitatif. Sugiyono (2017:8) mendefinisikan metode penelitian kuantitatif dapat diartikan sebagai metode yang berlandaskan filsafat positivisme, digunakan untuk meneliti pada populasi atau sampel tertentu, pengumpulan data menggunakan instrumen penelitian, analisis data 
bersifat kuantitatif atau statistik dengan tujuan untuk menguji hipotesis yang telah ditetapkan.

\section{Populasi dan Sampel}

1) Populasi adalah wilayah generalisasi yang terdiri atas obyek atau subyek yang mempunyai kualitas dan karakteristik tertentu yang ditetapkan oleh peneliti untuk dipelajari dan kemudian ditarik kesimpulannya (Sugiyono, 2017:80).

Populasi dalam penelitian ini adalah seluruh Pegawai Negeri Sipil yang bertugas pada Kantor Dinas Transmigrasi Kabupaten Banyuasin yang berjumlah 41orang.

2) Sampel adalah sebagian dari populasi yang mempunyai kualitas dan karakteristik itu sendiri. Apabila jumlah populasi relatif kecil, atau penelitian yang ingin membuat generalisasi dengan kesalahan yang sangat kecil maka teknik sampel yang digunakan adalah sampling jenuh. Penelitian ini menggunakan teknik sampling jenuh atau mengambil keseluruhan populasi sebagai sampel (Sugiyono, 2017:81).

Sampel yang digunakan pada penelitian ini adalah seluruh pegawai Pegawai Negeri Sipil pada Kantor Dinas Transmigrasi Kabupaten Banyuasin dan berjumlah 41 orang.

\section{Teknik Pengumpulan Data}

Teknik ini merupakan langkah yang paling strategis dalam penelitian karena tujuan utama dari penelitian adalah mendapatkan data (Sugiyono, 2017:137).

Teknik pengumpulan data yang digunakan yaitu:

a. Kuesioner, adalah teknik yang dilakukan dengan cara memberi seperangkat pertanyaan atau pernyataan tertulis kepada responden untuk dijawabnya. Berupa daftar pertanyaan atau angket tertulis yang sesuai dengan masalah penelitian.

b. Observasi, merupakan suatu proses yang kompleks, yang tersusun dari berbagai proses biologis dan psikologis. Dua di antara yang terpenting adalah proses-proses pengamatan dan ingatan.

\section{Teknik Analisis Data}

\section{1) Uji Instrumen}

$>\quad$ Uji Validitas

Menurut Sugiyono (2017:125) uji validitas menunjukkan derajat ketepatan antara data yang sesungguhnya terjadi pada objek dengan data yang dikumpulkan oleh peneliti. Untuk mencari validitas sebuah butir dilakukan melalui cara membandingkan nilai correlated itemtotal correlations $\left(r_{\text {hitung }}\right)$ dengan hasil perhitungan $r_{\text {tabel. }}$. Nilai $r_{\text {tabel }}$ dicari dengan taraf signifikan sebesar 0,05 pada derajat kebebas pada $\mathrm{df}=\mathrm{n}-2$. $\mathrm{Uj \textrm {j }}$ validitas pada penelitian ini menggunakan program Statistical Product Service Solutions (SPSS) Versi 22.

\section{$>\quad$ Uji Reliabilitas}

Uji reliabilitas menurut Sugiyono (2017:126) dilakukan untuk mengetahui seberapa jauh hasil pengukuran tetap konsisten apabila dilakukan pengukuran dua kali atau lebih terhadap gejala yang sama dengan menggunakan alat pengukur sama. Uji ini dilakukan untuk mengetahui apakah alat ukur yang dirancang dalam bentuk kuisioner dapat diandalkan, suatu alat ukur dapat diandalkan jika alat ukur tersebut digunakan berulang kali akan memberikan hasil yang relatif sama (tidak berbeda jauh).

Untuk melihat andal tidaknya suatu alat ukur digunakan pendekatan 
secara statistika, yaitu melalui koefisien reliabilitas dan apabila koefisien reliabilitasnya lebih besar dari 0.60 maka secara keseluruhan pernyataan tersebut dinyatakan andal (reliabel).Uji reliabilitas pada penelitian ini menggunakan metode Cronbach's Alpha. Uji reliabilitas ini menggunakan program Statistical Product Service Solutions (SPSS) Versi 22.

\section{2) Uji Asumsi Klasik}

Uji ini dilakukan agar model regresi yang digunakan dapat memberikan hasil yang representatif.

\section{Uji Normalitas}

Uji asumsi normalitas akan menguji data variabel bebas $(X)$ dan data variabel terikat $(Y)$ pada persamaan regresi yang dihasilkan, apakah berdistribusi normal atau berdistribusi tidak normal. (Sunyoto, 2013:84) Uji ini dapat dilakukan dengan analis grafik histogram dan normal probability plots yang dapat dideteksi dengan melihat penyebaran data (titik) pada sumbu diagonal dari grafik.

Dasar dari pengambilan sebuah keputusan adalah jika data menyebar sekitar garis normal dan mengikuti arah garis diagonal grafik, perihal ini ditunjukkan pada distribusi normal sehingga model persamaan regresi memenuhi asumsi normalitas sedangkan ketika data menyebar jauh dari garis diagonal dan tidak mengikuti arah garis diagonal grafik maka hal ini tidak menunjukkan bahwa distribusi normal sehingga persamaan regresi tidak memenuhi asumsi normalitas. Penyelesaian uji penelitian ini menggunakan program Statistical Product Service Solutions (SPSS) Versi 22.

\section{$>\quad$ Uji Multikolinieritas}

Priyatno (2015:99) menjelaskan, uji ini menganalisis regresi berganda yang terdiri dari dua atau tiga variabel bebas, atau variabel independen yaitu mengukur tingkat asosiasi (keeratan) hubungan pengaruh antara variabel bebas tersebut dengan melihat nilai tolerance dan inflation factor (VIF). Teknik dalam uji ini menggunakan Statistical Product Service Solutions (SPSS) for windows versi 22.

Dasar pengambilan keputusan adalah jika VIF > 10 atau jika tolerance $<0,1$ maka Ho ditolak dan Ha diterima sedangkan jika VIF $<10$ atau jika tolerance $>0,1$ maka Ho diterima dan Ha ditolak

\section{$>\quad$ Uji Heteroskedastisitas}

Uji heteroskedastisitas adalah keadaan dimana terjadi ketidaksamaan varian residu untuk pengamatan pada model regresi, Priyatno (2015:108). Uji ini terjadi pada scatterplot, titik-titiknya mempunyai pola teratur baik menyempit melebar maupun bergelombang-gelombang. Teknik yang digunakan dengan menggunakan program Statistical Product Service Solutions (SPSS) for windows 22.

Salah satu cara mendeteksi ada tidaknya heteroskedastisitas adalah melihat grafik plot antara nilai prediksi (ZPRED) dengan resresidualnya (SRESID). Deteksi ada atau tidaknya pola tertentu pada grafik scatterplot antara SRESID dan ZPRED dimana sumbu $Y$ adalah $Y$ yang telah diprediksi dan sumbu $X$ adalah residualnya $(Y$ prediksi $-Y$ sesungguhnya).

Dasar analisis uji heteroskedastisitas seandainya jika ada pola tertentu, seperti titik yang ada membentuk pola tertentu yang teratur (bergelombang, melebar kemudian menyempit) maka mengidikasikan telah terjadi heteroskedastisitas dan jika tidak ada pola yang jelas, serta titik-titik menyebar diatas dan dibawah 
angka 0 pada sumbu $Y$ maka tidak terjadi heteroskedastisitas.

Analisis
Berganda
Sugiyono menjelaskan analisis regresi digunakan untuk memprediksi seberapa jauh perubahan variabel dependen jika nilai variabel independen dirubah atau dinaikturunkan. Manfaat dari hasil analisis regresi adalah untuk membuat keputusan apakah naik dan menurunnya variabel dependen dapat dilakukan peningkatan variabel independen atau tidaknya. Untuk regresi yang variabel independennya terdiri atas atau lebih variabelnya maka disebut juga regresi berganda. Persamaan regresi dalam penelitian ini adalah untuk mengetahui seberapa besar pengaruh karakteristik individual dan lingkungan kerja terhadap kinerja pegawai. Penyelesaian persamaan regresi dalam penelitian ini menggunakan program Statistical Product Service Solutions (SPSS) for windows 22.

Persamaan regresi berganda dirumuskan:

$Y=a+b_{1} X_{1}+b_{2} X_{2}$

Sumber : Sugiyono (2017:275)

Keterangan:

$\mathrm{Y}=$ Variabel terikat kinerja pegawai

$\mathrm{a}=$ Bilangan konstanta

$\mathrm{b}_{1}=$ Koefisien karakteristik individu

$\mathrm{b}_{2}=$ Koefisien lingkungan kerja

$\mathrm{X}_{1}=$ Variabel bebas karakteristik individual

$\mathrm{X}_{2}=$ Variabel bebas lingkungan kerja

Koefisien Determinasi $\left(\mathbf{R}^{2}\right)$

Siregar (2013:338) menjelaskan koefisien determinasi $\left(R^{2}\right)$ adalah angka yang menyatakan atau digunakan untuk mengetahui konstribusi atau sumbangan yang diberikan oleh sebuah variabel bebas atau lebih terhadap variabel terikat. Penyelesaian perhitungan koefisien determinasi menggunakan Statistical Product Service Solutions (SPSS) for windows versi 22.

Rumus koefisien determinasi:

$R^{2}=(r)^{2} \times 100 \%$

Sumber : Siregar (2013:338)

Keterangan:

$\mathrm{R}^{2}=$ Koefisien Determinasi

$\mathrm{R}=$ Kuadrat Koefisien Korelasi

\section{4) Pengujian Hipotesis Uji Parsial (Uji t)}

Bahwa uji t digunakan untuk mengetahui apakah variabel independen secara parsial berpengaruh terhadap variabel dependen, Priyatno (2015:144). Kriteria pengujian dalam uji $\mathrm{t}$ adalah jika nilaisignifikan $\mathrm{t}>0,05$ maka Ho diterima sedangkan jika nilai signifikan $\mathrm{t}<$ 0,05 maka Ho ditolak. Penyelesaian pengujian hipoteisis dengan $u j i ~ t$ menggunakan Statistical Product Service Solutions (SPSS) for Windows versi 22.

\section{$>\quad$ Secara Simultan (Uji F)}

Priyatno (2015:89) bahwa uji $F$ (ANOVA atau analisis varian) merupakan uji koefisien regresi digunakan untuk mengetahui bahwa secara simultan karakteristik individual dan lingkungan kerja secara bersamasama terhadap kinerja pegawai. Kriteria pengujian dalam uji $\mathrm{F}$ adalah jika signifikan >0,05 maka Ho diterima dan $\mathrm{Ha}$ ditolak, jika signifikan $<0,05$ maka Ho ditolak dan Haditerima. Penyelesaian pengujian hipoteisis dengan uji $\mathrm{F}$ menggunakan Statistical 
Product Service Solutions (SPSS) for Windows versi 22.

\section{HASIL PENELITIAN}

1) Hasil Uji Coba Instrumen

Penelitian ini bertujuan untuk mengetahui pengaruh pada Kantor Dinas Transmigrasi Kabupaten Banyuasin dilakukan dengan cara menggunakan analisis regresi linier berganda dan analisis korelasi. Sebelum analisis regresi limier berganda dan analisis korelasi terlebih dahulu melakukan uji coba instrumen penelitian (kuesioner) untuk menyatakan validitas dan realibilitas. Uji Validitas dan realibilitas untuk mengetahui instrumen penelitian valid dan dapat dipercaya.

\section{$>\quad$ Hasil Uji Validitas}

Uji ini membandingkan nilai correlated item-total correlations ( $\mathrm{r}_{\text {hitung }}$ ) dengan hasil perhitungan $r_{\text {tabel. }}$. Nilai $r_{\text {tabel }}$ dicari dengan taraf signifikan sebesar 0,05 dan jumlah data sebanyak 41 dengan derajat kebebasan $\mathrm{df}=\mathrm{n}-2 \mathrm{dan}$ diperoleh nilai $r_{\text {tabelsebesar }} 0,308$. Hasil uji diperlihatkan berikut ini.

Tabel Hasil Uji Validitas Karakteristik Individu

\begin{tabular}{|c|c|c|c|c|}
\hline No & Butir Pertanyaan & $\mathbf{r}_{\text {hitung }}$ & $\mathbf{r}_{\text {tabel }}$ & Keterangan \\
\hline 1 & Butir 1 & 0,648 & 0,308 & Valid \\
\hline 2 & Butir 2 & 0,438 & 0,308 & Valid \\
\hline 3 & Butir 3 & 0,467 & 0,308 & Valid \\
\hline 4 & Butir 4 & 0,423 & 0,308 & Valid \\
\hline 5 & Butir 5 & 0,409 & 0,308 & Valid \\
\hline 6 & Butir 6 & 0,533 & 0,308 & Valid \\
\hline 7 & Butir 7 & 0,540 & 0,308 & Valid \\
\hline 8 & Butir 8 & 0,625 & 0,308 & Valid \\
\hline 9 & Butir 9 & 0,487 & 0,308 & Valid \\
\hline 10 & Butir 10 & 0,415 & 0,308 & \\
\hline
\end{tabular}

Sumber: Data Diolah Dengan Program SPSS Versi 22

Diketahui bahwa semua butir pertanyaan diatas valid untuk variabel karakteristik individual karena nilai $r$ hitung pada butir 1 hingga butir 10 memiliki nilai yang lebih besar dari $r_{\text {tabel }}$
$=0,308$, dengan demikian butir-buitr kuisioner pada variabel karakteristik individual dapat digunakan sebagai instrumen penelitian.

Tabel Hasil Uji Validitas Lingkungan Kerja

\begin{tabular}{|c|c|c|c|c|}
\hline No & Butir Pertanyaan & $\mathbf{r}_{\text {hitung }}$ & $\mathbf{r}$ tabel & Keterangan \\
\hline 1 & Butir 1 & 0,446 & 0,308 & Valid \\
\hline 2 & Butir 2 & 0,506 & 0,308 & Valid \\
\hline 3 & Butir 3 & 0,518 & 0,308 & Valid \\
\hline 4 & Butir 4 & 0,443 & 0,308 & Valid \\
\hline 5 & Butir 5 & 0,627 & 0,308 & Valid \\
\hline 6 & Butir 6 & 0,422 & 0,308 & Valid \\
\hline 7 & Butir 7 & 0,525 & 0,308 & Valid \\
\hline 8 & Butir 8 & 0,458 & 0,308 & Valid \\
\hline 9 & Butir 9 & 0,521 & 0,308 & Valid \\
\hline 10 & Butir 10 & 0,450 & 0,308 & \\
\hline
\end{tabular}

Sumber: Data Diolah Dengan Program SPSS Versi 22

Dapat diketahui bahwa semua butir pertanyaan valid untuk variabel lingkungan kerja karena nilai $r_{\text {hitung butir }}$ 1 hingga ke butir 10 mempunyai nilai yang lebih besar dari $r_{\text {tabel }}=0,308$, dengan demikian butir-buitr kuisioner pada variabel lingkungan kerja individual dapat digunakan sebagai instrumen penelitian. 
Tabel Hasil Uji Validitas Kinerja Pegawai

\begin{tabular}{|c|c|c|c|c|}
\hline No & Butir Pertanyaan & $\mathbf{r}$ hitung & $\mathbf{r}$ tabel & Keterangan \\
\hline 1 & Butir 1 & 0,327 & 0,308 & Valid \\
\hline 2 & Butir 2 & 0,573 & 0,308 & Valid \\
\hline 3 & Butir 3 & 0,315 & 0,308 & Valid \\
\hline 4 & Butir4 & 0,463 & 0,308 & Valid \\
\hline 5 & Butir 5 & 0,438 & 0,308 & Valid \\
\hline 6 & Butir 6 & 0,355 & 0,308 & Valid \\
\hline 7 & Butir 7 & 0,481 & 0,308 & Valid \\
\hline 8 & Butir 8 & 0,585 & 0,308 & Valid \\
\hline 9 & Butir 9 & 0,459 & 0,308 & Valid \\
\hline 10 & Butir 10 & 0,432 & 0,308 & Valid \\
\hline
\end{tabular}

Sumber: Data Diolah Dengan Program SPSS Versi 22

Berdasarkan hasil pada tabel, bahwa kesemua butir pertanyaan diatas dinyatakan valid, karena seluruh nilai $r$ hitung dari butir 1 hingga 10 mempunyai nilai yang lebih besar dari $r_{\text {tabel }}=0,308$ dengan demikian butirbuitr kuisioner pada variabel kinerja pegawai dapat digunakan sebagai instrumen penelitian.

\section{$>\quad$ Hasil Uji Reliabilitas}

Uji ini untuk mengetahui apakah indikator atau kuesioner yang digunakan dapat dipercaya atau handal sebagai alat ukur variabel. Reliabilitas sebuah indikator atau kuesioner dapat dilihat dari nilai Cronbach Alpha ( $\alpha$ ), yaitu apabila cronbach alpha $(\alpha)>0,60$ maka indikator atau kuesioner adalah reliabel, sedangkan apabila nilai cronbach alpha $(\alpha)<0,60$ maka indikator atau kuesioner tidak reliabel.

\section{Tabel Hasil Uji Reliabilitas Variabel Karakteristik Individu Reliability Statistics

\begin{tabular}{|c|c|}
\hline Cronbach's Alpha & N of Items \\
\hline .659 & 10 \\
\hline
\end{tabular} \\ Sumberi Data Diolah Dengan Program SPSS Versi 22}

Hasil uji nilai Cronbach' Alpha pada tabel di atas, didapat sebesar $0,659>0,60$ karena nilai tersebut 0,60 maka dapat disimpulkan instrument tersebut reliabel (dapat dipercaya), dengan demikian butir-butir kuisioner dapat dijadikan instrumen dalam penelitian ini.

Hasil Uji Reliabilitas Variabel Lingkungan Kerja Reliability Statistics

\begin{tabular}{|c|c|}
\hline Cronbach's Alpha & N of Items \\
\hline .642 & 10 \\
\hline
\end{tabular}

Sumber : data diolah ( SPSS Ver. 22) 
Dari hasil yang dilihat pada tabel di atas, didapat nilai Cronbach' Alpha sebesar 0,642>0,60, nilai diatas 0,60 dapat disimpulkan bahwa instrumen tersebut reliabel (dapat dipercaya), dengan demikian dapat dijadikan instrumen pada penelitian ini.

Hasil Uji Reliabilitas Variabel Kinerja Pegawai

\begin{tabular}{|c|c|}
\hline Cronbach's Alpha & N of Items \\
\hline .645 & 10 \\
\hline
\end{tabular}

Sumber : data diolah (SPSS Versi 22)

Nilai Cronbach' Alpha pada tabel diatas sebesar 0,645>0,60 karena nilai tersebut diatas 0,60 maka disimpulkan bahwa instrumen tersebut reliabel (dapat dipercaya), artinya dapat dijadikan instrumen dalam penelitian ini.

\section{2) Hasil Uji Asumsi Klasik $>\quad$ Uji Normalitas}

Data variabel bebas dan data variabel terikat pada model regresi yang digunakan, akan di uji dengan uji normalitas, apakah berdistribusi normal atau tidak. Uji ini dilakukan dengan analisis grafik histogram dan normal probability plots yang dapat dideteksi dengan melihat penyebaran data (titik) pada sumbu diagonal dari grafik.

Dasar pengambilan sebuah keputusan ialah jika data menyebar disekitar garis normal dan mengikuti arah garis diagonal grafik menunjukkan distribusi normal sehingga model persamaan memenuhi asumsi normalitas sedangkan jika data menyebar jauh dari diagonal dan tidak mengikuti arah garis diagonal grafik maka tidak menunjukkan pada distribusi normal sehingga persamaan regresi tidak memenuhi asumsi normalitas.

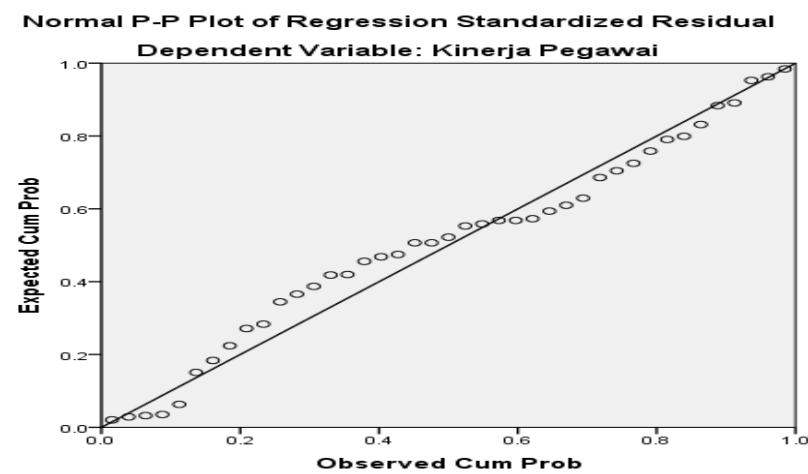

Gambar Hasil Uji Normalitas

Sumber : data diolah (SPSS Versi 22)

Terlihat pada grafik normal probability plot garis (titik-titik) mengikuti garis diagonal grafik yang artinya dalam penelitian ini data berdistribusi normal, dengan demikian analisis dapat dilanjutkan.

\section{Uji Multikolinearitas}


Uji multikolinearitas berarti ada hubungan liniear yang sempurna atau pasti di antara beberapa atau semua variabel bebas. Akibat adanya multikolinearitas ini koefisien regresi tidak tertentu dan kesalahan standarnya tidak terhingga. Tujuan uji multikolinearitas untuk menguji model regresi terjadi atau tidaknya korelasi diantara variabel bebas. Metode untuk menguji adanya multikolinearitas dilihat dari tolerance value atau variance inflantion factor (VIF).Batas dari tolerance value $>0,10$ atau nilai $\mathrm{VIF}<$ 10 maka tidak terjadi multikolinearitas

\section{Tabel Hasil Uji Multikolinearitas}

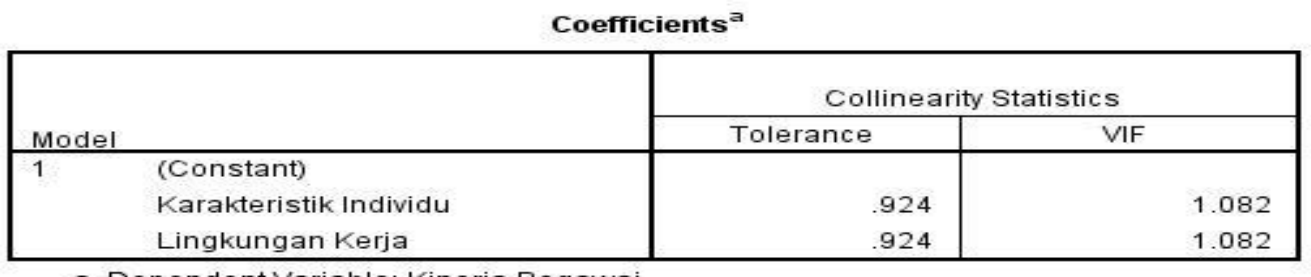

a. Dependent Variable: Kinerja Pegawai

\section{Sumber : data diolah (SPSS Versi 22)}

Berdasarkan hasil uji multikolinearitas, bahwa nilai tolerance variabel karakteristik individu dan lingkungan kerja 0,924>0,10 dan nilai VIF (Variance Inflation Factor) variabel karakteristik individual dan lingkungan kerja $1,082<10$ maka dapat disimpulkan tidak terjadi multikolinearitas.

\section{$>\quad$ Uji Heteroskedastisitas}

Uji Heterokedasitas adalah suatu keadaan dimana varian dan kesalahan penganggu tidak konstan untuk semua variabel bebas. Model regresi yang baik adalah tidak terjadi heteroskedastisitas. Uji heteroskedastisitas dilakukan dengan melihatpola garis pada scatterplot.

Dasar dari pengambilan sebuah keputusan adalah jika hasil pola membentuk pola tertentu yang teratur (bergelombang, melebar kemudian menyempit) maka diidentifikasi terjadi heteroskedastisitas sedangkan jika hasil pola menyebar diatas dan dibawah angka nol pada sumbu $\mathrm{Y}$, maka tidak terjadi heteroskedastisitas.

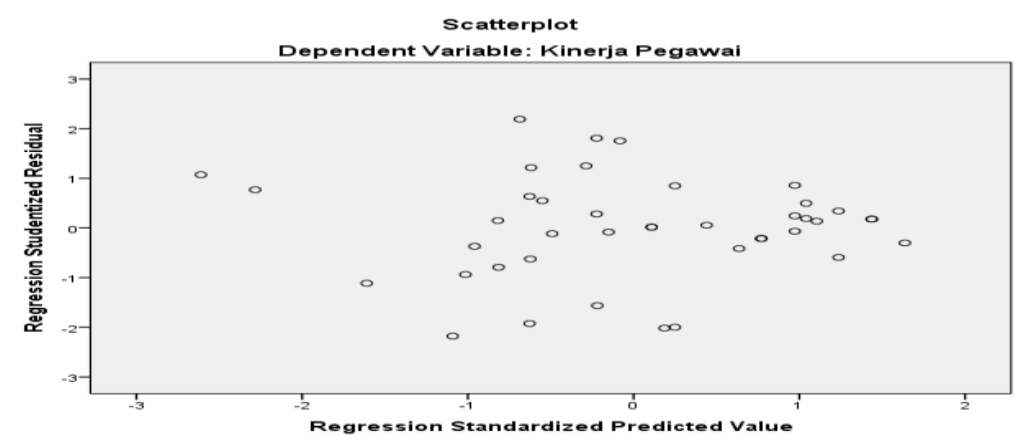

Gambar Hasil Uji Heteroskedastisitas

Sumber : data diolah (SPSS Versi 22) 
Pada gambar diatas terlihat hasil pola menyebar diatas dan dibawah angka nol pada sumbu Y. Hal ini menunjukkan bahwa tidak terjadi heteroskedastisitas sehingga model regresi dapat digunakan.

\section{3) Hasil Analisis Regresi Linier Berganda}

Analisis regresi ini bertujuan untuk mengetahui ada tidaknya pengaruh antara variabel bebas terhadap variabel terikat dimana terdapat tiga variabel karakteristik individu dan lingkungan kerja merupakan variabel bebas dan kinerja pegawai sebagai variabel terikat.

\section{Tabel Hasil Uji Regresi Linier Berganda}

\begin{tabular}{|c|c|c|c|c|c|c|}
\hline \multicolumn{7}{|c|}{ Coefficients $^{a}$} \\
\hline \multirow{2}{*}{\multicolumn{2}{|c|}{ Model }} & \multicolumn{2}{|c|}{ Unstandardized Coefficients } & \multirow{2}{*}{$\begin{array}{c}\begin{array}{c}\text { Standardized } \\
\text { Coefficients }\end{array} \\
\text { Beta } \\
\end{array}$} & \multirow[b]{2}{*}{$t$} & \multirow[b]{2}{*}{ Sig. } \\
\hline & & B & Std. Error & & & \\
\hline \multirow[t]{3}{*}{1} & (Constant) & .536 & .730 & & .734 & .467 \\
\hline & Karakteristik Individu & .346 & .131 & .346 & 2.638 & .012 \\
\hline & Lingkungan Kerja & .525 & .157 & .439 & 3.349 & .002 \\
\hline
\end{tabular}

a. Dependent Variable: Kinerja Pegawai

\section{Sumber: data diolah (SPSS Versi 22)}

Hasil uji yang diperoleh berdasarkan tabel diatas, nilai koefisien regresi pada variabel karakteristik individual $\left(\mathrm{X}_{1}\right)$ adalah 0,346 dan nilai koefisien regresi untuk variabel lingkungan kerja $\left(\mathrm{X}_{2}\right)$ sebesar 0,525 dan nilai konstanta sebesar 0,536. Dari nilai tersebut, diperoleh persamaan regresi linier berganda adalah $Y=0,536+0,346 X_{1}+0,525 X_{2}$ dimana konstanta a bernilai 0,536 , koefisien regresi b1 bernilai 0,346 dan b2 sebesar 0,525.

\section{Hasil Analisis Koefisien Determinasi}

Koefisien determinasi $\left(R^{2}\right)$ adalah angka yang menyatakan atau digunakan untuk mengetahui kontribusi atau sumbangan yang diberikan oleh satu atau lebih variabel bebas terhadap variabel terikat.

\section{Tabel Hasil Analisis Koefisien Determinasi}

\begin{tabular}{|l|c|c|c|c|}
\hline Model & $R$ & R Square & $\begin{array}{c}\text { Adjusted R } \\
\text { Square }\end{array}$ & $\begin{array}{c}\text { Std. Error of } \\
\text { the Estimate }\end{array}$ \\
\hline 1 & $.629^{\mathrm{a}}$ & .396 & .364 & .33240 \\
\hline
\end{tabular}
$\begin{aligned} & \text { a. Predictors: (Constant), Lingkungan Kerja, Karakteristik } \\
& \text { Individu }\end{aligned}$

Sumber : data diolah (SPSS Versi 22) 
Diketahui bahwa nilai koefisien determinasi (Adjusted $R$ Square) sebesar 0,396 atau $39,6 \%$.

\section{4) Hasil Uji Hipotesis}

\section{$>\quad$ Hasil Uji Parsial (Uji t)}

Dengan menggunakan uji parsial atau uji $\mathrm{t}$ adalah pengujian terhadap koefisien regresi secara parsial. Batas signifikannya yang digunakan adalah $5 \%$. Signifikan artinya meyakinkan atau dapat berlaku untuk populasi.
Penarikan kesimpulan uji t dilakukan dengan membandingkan nilai Sig. $t$ dengan $\square$ sebesar 0,05 , jika nilai Sig $t$ $>0,05$ maka Ho diterima sedangkan jika nilai Sig. $\mathrm{t}<0,05$ maka Ho ditolak dan Ha diterima.

Tabel berikut ini memperlihatkan hasil uji $t$ dengan variabel bebas karakteristik individual dan lingkungan kerja serta variabel terikat kinerja pegawai.

\section{Tabel Hasil Uji t}

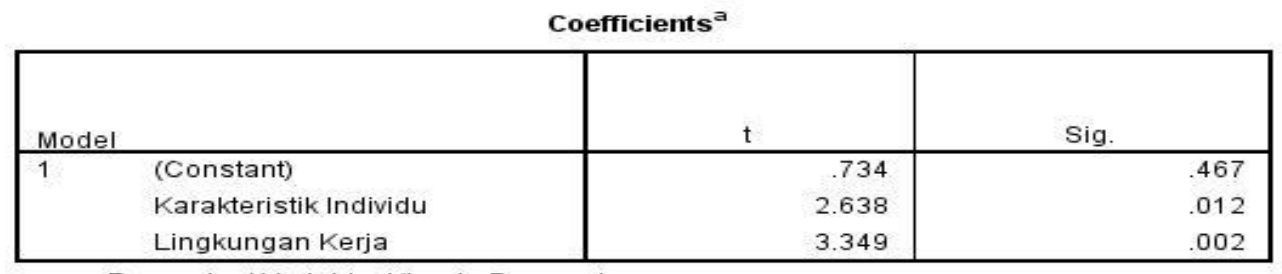

a. Dependent Variable: Kinerja Pegawai

Sumber : data diolah (SPSS Versi 22)

Dari hasil pada tabel di atas memperlihatkan nilai Sig. t variabel karakteristik individual sebesar 0,012 yang berarti $\mathrm{H}_{\mathrm{o}}$ ditolak, $\mathrm{H}_{\mathrm{a}}$ diterima. Sedangkan untuk variabel lingkungan kerja 0,002 yang berarti $\mathrm{H}_{0}$ diterima.

\section{$>\quad$ Hasil Uji Simultan (Uji F)}

Uji hipotesis dengan uji simultan atau uji $F$ adalah pengujian terhadap koefisien regresi secara simultan. Batas signifikan yang digunakan adalah 5\%. Signifikan artinya menyakinkan atau dapat berlaku untuk populasi. Penarikan kesimpulan uji $F$ adalah membandingkan nilai Sig $F$ dengan $\square$ sebesar 0,05, jika Sig. F > 0,05 maka Ho diterima sedangkan jika Sig. $\mathrm{F}<0,05$ maka $\mathrm{Ho}$ ditolak dan $\mathrm{Ha}$ diterima.

Tabel berikut ini memperlihatkan hasil uji $t$ dengan variabel bebas karakteristik individual dan lingkungan kerja serta variabel terikat kinerja pegawai.

\section{Tabel Hasil Uji F}

ANOVA $^{a}$

\begin{tabular}{|ll|r|r|r|r|c|}
\hline Model & & $\begin{array}{c}\text { Sum of } \\
\text { Squares }\end{array}$ & df & Mean Square & F & Sig. \\
\hline 1 & Regression & 2.754 & 2 & 1.377 & 12.461 & $.000^{\mathrm{b}}$ \\
& Residual & 4.199 & 38 & .110 & & \\
& Total & 6.952 & 40 & & & \\
\hline
\end{tabular}

a. Dependent Variable: Kinerja Pegawai

b. Predictors: (Constant), Lingkungan Kerja, Karakteristik Individu

Sumber : data diolah (SPSS Ver. 22) 
Dari tabel hasil uji $F$ diatas memperlihatkan nilai Sig. F sebesar 0,000 berarti $\mathrm{Ho}$ ditolak dan $\mathrm{Ha}$ diterima.

\section{E. PEMBAHASAN}

Dari hasil regresi linier berganda diperoleh nilai konstanta a sebesar 0,536 memberikan arti jika karakteristik individual pegawai dan lingkungan kerja tidak mendukung kinerja pegawai maka nilai kinerja pegawai sebesar 0,536 satuan. Koefisien regresi b1 dengan variabel karakteristik individual sebesar 0,346 memberikan arti jika terjadi peningkatan pada karakteristik individual sebesar 1 satuan maka variabel kinerja pegawai akan mengalami peningkatan sebesar 0,346 satuan. Koefisien regresi b2 dengan variabel lingkungan kerja sebesar 0,525 memberikian arti jika terjadi peningkatan pada lingkungan kerja sebesar 1 satuan maka nilai variabel kinerja pegawai mengalami peningkatan sebesar 0,525 satuan. Sehingga persamaannya adalah $\mathrm{Y}=$ $0,536+0,346 X_{1}+0,525 X_{2}$.

Koefisien determinasi (Adjusted $R$ Square) yaitu sebesar 0,396 atau 39,6 memberikan arti kontribusi variabel karakteristik individual dan lingkungan kerja terhadap kinerja pegawai sebesar $39,6 \%$ sedangkan sisanya sebesar $60,4 \%$ dipengaruhi oleh faktor-faktor lain yang tidak diteliti. Faktor tersebut diantaranya kedisiplinan, motivasi, kepuasan kerja dan lain-lain.

$\begin{array}{rcc}\text { Uji } & \text { hipotesis (uji t) dengan } \\ \text { variabel } & \text { karakteristik } & \text { individu }\end{array}$ menghasilkan nilai Sig t sebesar 0,012 yang berarti $\mathrm{Ho}$ ditolak dan $\mathrm{Ha}$ diterima, dengan demikian secara parsial, karakteristik individual berpengaruh signifikan terhadap kinerja pegawai. Hasil uji t dengan variabel lingkungan kerja menghasilkan nilai Sig t sebesar 0,002 berarti Ho diterima, dengan demikian secara parsial lingkungan kerja berpengaruh tidak signifikan terhadap kinerja pegawai.

Uji hipotesis (uji F) menghasilkan nilai Sig. F sebesar 0,000 berarti $\mathrm{Ho}$ ditolak dan $\mathrm{Ha}$ diterima, dengan demikian secara simultan karakteristik individual dan lingkungan kerja berpengaruh signifikan terhadap kinerja pegawai Kantor Dinas Transmigrasi Kabupaten Banyuasin.

\section{F. KESIMPULAN DAN SARAN \\ 1. Kesimpulan}

Berdasarkan analisis data dan pembahasan yang telah dijabarkan pada bab sebelumnya, maka dalam penelitian ini diperoleh kesimpulan sebagai berikut:

a. Secara parsial, karakteristik individual berpengaruh terhadap kinerja pegawai.

b. Secara parsial lingkungan kerja berpengaruh terhadap kinerja pegawai.

c. Secara simultan karakteristik individual dan lingkungan kerja berpengaruh terhadap kinerja pegawai Kantor Dinas Transmigrasi Kabupaten Banyuasin.

\section{Saran}

Beberapa saran yang ingin penulis sampaikan kepada pihak Kantor Dinas Transmigrasi Kabupaten Banyuasin adalah:

a. Mengingat berdasarkan hasil penelitian ini diperoleh hasil adanya pengaruh karakteristik individual terhadap kinerja pegawai secara signifikan maka penulis menyarankan untuk terus menanamkan nilai-nilai luhur dan pendidikan karakter kepada bawahannya agar kinerja para pegawai juga terus meningkat. 
b. Berdasarkan hasil penelitian ini diperoleh hasil adanya pengaruh lingkungan kerja terhadap kinerja pegawai secara tidak signifikan maka penulis menyarankan untuk terus mempertahankan kualitas dan kenyamanan lingkungan kerja masing-masing, dengan demikian kinerja pegawai dapat terus meningkat.

\section{DAFTAR PUSTAKA}

Hurriyati, Ratih. 2011. Bauran Pemasaran dan Loyalitas Konsumen. Bandung: Alfabeta.

Nuraida, Ida. 2014. Manajemen Administrasi Perkantoran (Edisi Revisi). Yogyakarta: PT. Kanisius.

Priyatno, Duwi. 2015. SPSS 20 Pengolahan Data Terpraktis. Yogyakarta: Andi Offset.

Rahman, Abdul. 2013. Psikologi Sosial: Integrasi Pengetahuan Wahyu dan Pengetahuan Empirik. Jakarta: Rajawali Pers.

Sedarmayanti. 2011. Tata Kerja dan Produktivitas Kerja (Suatu Tinjauan dari Aspek Ekonomi Antara Manusia dengan
Lingkungan Kerjanya). Bandung: CV. Mandar Maju.

Siregar, Syofian. 2013. Metode Penelitian Kuantitatif. Jakarta: PT. Fajar Interpratama Mandiri.

Sugiyono. 2017. Metode Penelitian Kuantitatif, Kualitatif dan $R$ \& D.Bandung: Alfabeta.

Sunyoto, Danang. 2013. Analisis Regresi dan Uji Hipotesi. Cetakan Pertama.Jakarta : PT. Buku Kita.

2015. Penelitian Sumber Daya Manusia. Jakarta: PT. Buku Seru.

Thoha, Miftah. 2016. Perilaku Organisasi: Konsep Dasar dan Aplikasinya. Jakarta: Rajawali Pers.

Uha, Nawawi. Ismail. 2013. Budaya Organisasi Kepemimpinan \& Kinerja (Edisi ke 1). Jakarta: Prenada Media Group.

2014. Manajemen Perubahan (Cetakan Pertama). Bogor: Ghalia Indonesia.

Wibowo. 2014. Manajemen Kinerja. Jakarta: PT. Raja Grafindo 